



\section{Monitoring van het helingsproces van de navelstrengen van geitenlammeren}

Jan Verkaik, Ingrid van Dixhoorn, Henk Gunnink, Theo van Hattum, Wijbrand Ouweltjes

Dit onderzoek is uitgevoerd door Wageningen Livestock Research, in opdracht van en gefinancierd door het Ministerie van Economische Zaken, in het kader van het Beleidsondersteunend onderzoek thema 'Dierenwelzijn' (projectnummer BO-20-008-013)

Wageningen Livestock Research

Wageningen, december 2016

Livestock Research Rapport 992 
Jan Verkaik, Ingrid van Dixhoorn, Henk Gunnink, Theo van Hattum, Wijbrand Ouweltjes, 2016.

Monitoring van het helingsproces van de navelstrengen van geitenlammeren. Wageningen Livestock Research, rapport 992.

Dit rapport is gratis te downloaden op http://dx.doi.org/10.18174/399811 of op www.wur.nl/livestock-research (onder Wageningen Livestock Research publicaties).

(C) 2016 Wageningen Livestock Research

Postbus 338, 6700 AH Wageningen, T 03174839 53, E info.livestockresearch@wur.nl, www.wur.nl/livestock-research. Wageningen Livestock Research is onderdeel van Wageningen University \& Research.

Wageningen Livestock Research aanvaardt geen aansprakelijkheid voor eventuele schade voortvloeiend uit het gebruik van de resultaten van dit onderzoek of de toepassing van de adviezen.

Alle rechten voorbehouden. Niets uit deze uitgave mag worden vermenigvuldigd en/of openbaar gemaakt worden door middel van druk, fotokopie, microfilm of op welke wijze dan ook zonder voorafgaande toestemming van de uitgever of auteur. onderzoeksopdrachten zijn de Algemene Voorwaarden van de Animal Sciences Group van toepassing. Deze zijn gedeponeerd bij de Arrondissementsrechtbank Zwolle.

Wageningen Livestock Research Rapport 992. 


\section{Inhoud}

$\begin{array}{ll}\text { Samenvatting } & \mathbf{5}\end{array}$

$\begin{array}{lll}1 & \text { Inleiding } & 7\end{array}$

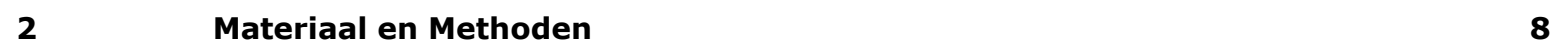

$\begin{array}{lll}2.1 & \text { Bedrijfsspecifieke gegevens } & 8\end{array}$

2.2 Individuele diergegevens $\quad 8$

$\begin{array}{llr}3 & \text { Resultaten } & 9\end{array}$

$\begin{array}{lll}3.1 & \text { Bedrijfsspecifieke gegevens } & 9\end{array}$

$\begin{array}{ll}3.2 & \text { Resultaten monitoring } \\ 3.3 & 10\end{array}$

$\begin{array}{ll}3.3 & \text { Indroging } \\ 3.4 & 10\end{array}$

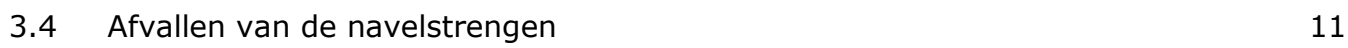

3.5 Afwijkende heling $\quad 12$

$\begin{array}{lll}3.6 & \text { Fotoseries } & 13\end{array}$

4

$\begin{array}{lr}\text { Conclusies } & 19\end{array}$

$\begin{array}{ll}\text { Literatuur } & 20\end{array}$

$\begin{array}{lll}\text { Bijlage } 1 & \text { Scoringsprotocol } & 21\end{array}$ 



\section{Samenvatting}

Volgens de Europese wetgeving mogen jonge lammeren pas getransporteerd worden over een afstand langer dan 100 kilometer, indien ze ouder zijn dan een week. Voor alle transporten, kort en lang, geldt dat de navel compleet moet zijn geheeld. Om een indicatie te krijgen van het uitwendige helingsproces van navels is op twee geitenbedrijven in Nederland het indrogings- en mummificatieproces van de navels gevolgd en vastgelegd met foto's.

De duur van het mummificatieproces van de uitwendige navel varieert. Op 2 dagen na geboorte heeft $50 \%$ een volledig gemummificeerde navel en op 4 dagen na de geboorte is dat meer dan $90 \%$. Op een leeftijd van 7 dagen lijkt de mummificatie van de navelstreng van alle geitenlammeren voltooid. Op basis van dit onderzoek wordt ingeschat dat het afvallen van de navel pas na 21 dagen na geboorte gebeurt.

Het geboortegewicht, de diameter van de navelstreng of de lengte van de navelstreng zijn geen goede indicatoren voor het helingproces van de navels. 


\section{$1 \quad$ Inleiding}

Volgens de Europese wetgeving mogen jonge lammeren pas getransporteerd worden over een afstand langer dan 100 kilometer, indien ze ouder zijn dan een week én wanneer de navel compleet geheeld is. Ook voor transporten over minder dan 100 kilometer moet de navel compleet geheeld zijn. Met handhaving belaste NVWA-medewerkers hebben de indruk dat er geitenlammeren worden vervoerd die daarvoor nog niet geschikt zijn (te jong en/of met een nog kwetsbare navelstreng). Goede hulpmiddelen om de criteria te handhaven ontbreken. Handhaving van regelgeving op basis van leeftijd (controle of de lammeren minimaal 7 dagen oud zijn) wordt niet realistisch geacht omdat de registratie van geboortedata van de lammeren onvoldoende betrouwbaar is.

Het is niet goed bekend hoe de heling van de navelstreng vanaf de geboorte in de tijd verloopt en wat belangrijke factoren zijn die dit proces beïnvloeden. Ten behoeve van haar taakuitoefening (in casu het handhaven van regelgeving m.b.t. diertransport) heeft de NVWA behoefte aan duidelijke en praktisch bruikbare criteria om te beoordelen of navelstrengen van jonge geitenlammeren zijn geheeld.

Hoewel de regelgeving spreekt van volledige heling als criterium voor "fitness" voor transport (dus inclusief inwendige fysiologische processen), kan in de praktijk heling alleen op grond van uitwendig waarneembare verschijnselen worden beoordeeld. Bij kalveren is beschreven dat het 10-14 dagen duurt tot het gemummificeerde navelstreng-weefsel is afvallen en aansluitend nog eens 2-4 dagen extra voordat het navelwondje is genezen ( $\mathrm{H}$. Bostedt, 1997). Bij het helingsproces wordt de tijd als meest belangrijke factor beschouwd, er is echter veel variatie tussen dieren in het verloop van het helingsproces in de tijd ( $\mathrm{H}$. Bostedt, 1997).

Doel van dit project is het beschrijven van veranderingen in een aantal uitleesparameters die de uitwendige status van navelstrengen van geitenlammeren ("helingsproces") weergeven gedurende de eerste 14 dagen na de geboorte, en het samenstellen van hulpmiddelen bij de beoordeling van navelstrengen in de praktijk. Dit onderzoek richt zich derhalve puur op de heling van de uitwendige navelstreng als beoordelingscriterium voor geschiktheid voor transport. Met dit onderzoek kunnen geen uitspraken worden gedaan over de daadwerkelijke leeftijd van de lammeren op het moment van vervoer. Het project levert een beknopte rapportage op waarin de toestand van navelstrengen van geitenlammeren gedurende de eerste 14 dagen vanaf de geboorte op twee praktijkbedrijven wordt beschreven. Zowel gemiddelde als variatie tussen dieren wordt daarin meegenomen. De resultaten leveren een indicatie op van de bandbreedte in dagen waarbinnen (volledige) heling plaatsvindt, maar in de praktijk kan de bandbreedte groter zijn met name door managementfactoren. De opzet van dit project is niet geschikt om daar goed inzicht in te krijgen, daarvoor zouden gegevens moeten worden verzameld op een veel groter aantal bedrijven.

De resultaten van dit project helpen zowel veehouders, vervoerders als handhavers te beoordelen of jonge geitenlammeren vervoerd mogen worden. Dit draagt bij aan het naleven van wettelijke verplichtingen bij diertransport in en vanuit Nederland.

Literatuur over heling van navelstrengen is zeer beperkt. Er is één bestaand artikel, gericht op heling van navelstrengen bij kalveren geraadpleegd. Mede op basis hiervan is een concept protocol gemaakt voor de verzameling van gegevens die relevante kenmerken van de navelstreng beschrijven. Het beoogde protocol wordt met bijbehorende scoreformulieren voor het doen van waarnemingen vooraf uitgetest op één geitenbedrijf, waar op dat moment jonge geitjes zijn van 0 tot 14 dagen oud. Op twee bedrijven zijn vervolgens per bedrijf circa 50 dieren op verschillende momenten gescoord tussen dag van de geboorte en minimaal 14 dagen leeftijd. Deze opzet geeft tevens de mogelijkheid om bij een deel van de dieren ook op oudere leeftijd (>14 dagen) de navelstreng te beoordelen, om zo een indicatie te krijgen hoe lang het duurt voordat de navelstreng is afgevallen. Bij ieder dier werd per beoordeling een foto gemaakt.

$\mathrm{Er}$ is een eenvoudige beschrijvende analyse uitgevoerd en een overzicht van het verloop van het uitwendige helingsproces voor de beoordeelde kenmerken in de eerste weken na de geboorte en de variatie daarin op grond van de bevindingen is weergegeven in deze rapportage. Een aantal typische fotoseries zijn in dit rapport opgenomen. 


\section{Materiaal en Methoden}

\subsection{Bedrijfsspecifieke gegevens}

De behandelingen van de lammeren na hun geboorte en tijdens de opfok zijn per bedrijf beschreven. De onderdelen: huisvesting, aard van het ligbed (droog/nat), ontsmetting van de navelstreng en de biestvoorziening zijn hierin opgenomen. Per lam is het individuele diernummer, de geboortedatum, het geslacht en de bestemming vastgelegd.

Vanaf de start-dag worden op elk bedrijf tot ca. 50 lammeren met een leeftijd tot 3 dagen oud in de proef genomen. Elk van deze ca. 50 lammeren is minimaal 14 dagen gevolgd, met minimaal één intake waarneming en één eindwaarneming op de laatste monitoringsdag. Tussentijdse waarnemingen zijn uitgevoerd bij lammeren waarbij de navelstreng nog niet volledig is opgedroogd of heling een afwijkend beeld gaf (ontstekingen en breuken). Voor het verkrijgen van een indicatie van de leeftijd bij afvallen werd op 1 bedrijf daarnaast ook een beperkt aantal iets oudere lammeren in de proef genomen.

\subsection{Individuele diergegevens}

Het helingsproces van de navelstreng van geitenlammeren is gemonitord aan de hand van een scoreformulier (bijlage 1) op de onderstaande parameters:

- Gewicht van de pasgeboren lammeren; gewogen in kilogrammen (2 cijfers achter de komma) met een digitale hangweegschaal en emmer. 1 meting per lam bij het in de proef nemen van het lam.

- Indruk van het dier; fris, gezond, ziek/ziek t.g.v. navelinfectie, onderkoeld, ondervoed / turgor (op een vaste plek ter hoogte van de ribben gemeten).

- Status van de huid rond de navelstreng op de tast; typering van de huid rond de navelstreng door deze te palperen bij het staande lam ter plekke van de aanhechting aan het lichaam en te beoordelen als soepel/gesloten of als stug/verdikt/hard. Deze waarneming is alleen op bedrijf 1 toegepast en geschrapt voor bedrijf 2 vanwege mogelijke interferentie met het helingsproces.

- Status van de huid rond de navelstreng visueel; typering van de huid rond de navelstreng ter plekke van de aanhechting aan het lichaam vochtig / indrogend / opgedroogd / zichtbaar ontstoken / gezwollen / kleur? / open / dicht.

- Status van de navelstreng zelf; vochtig / indrogend / opgedroogd (gemummificeerd) / afgescheurd / losgelaten.

- Diameter van de navelstreng; gemeten in de breedte van het lam en op de buik van het lam op het punt van de aanhechting, zonder deze in te drukken met een digitale schuifmaat tot 2 cijfers achter de komma. Gemeten bij de eerste scoringsdag. Indien de navelstreng als afwijkend werd beschouwd, werd ook de diameter op latere scoringsdagen gemeten.

- Lengte van de navelstreng; loshangend gemeten en/of geschat met behulp van de schuifmaat vanaf de aanhechting in 4 categorieën $(1=<1 \mathrm{~cm} ; 2=1-5 \mathrm{~cm} ; 3=5-10 \mathrm{~cm} ; 4=>10 \mathrm{~cm})$ De navelstreng wordt niet rechtgetrokken voor de meting.

Daarnaast was er ruimte voor overige opmerkingen: zoals een navelbreuk, individuele behandelingen van de lammeren gedurende de proefperiode; soort behandeling en reden van behandeling, uitval en reden bij uitval in proefperiode, afvoer mesterij/opfok, sterfte indien bekend de oorzaak, ziekte soort (bv dik oor / oorontsteking / gewrichtsontsteking / overkoot).

Van alle lammeren op iedere scoringsdag werd een close up foto van de navelstreng gemaakt. 


\subsection{Bedrijfsspecifieke gegevens}

Op bedrijf 1 waren 950 melkgeiten aanwezig. Jaarlijks worden in 3 of 4 perioden de lammeren geboren, te weten half december, januari/begin februari, maart en mei. In die perioden werpen respectievelijk rond de 50 melkgeiten (welke kunstmatig zijn geïnsemineerd), 900 melk- en opfokgeiten, 50 opfokgeiten en eventuele restant van de opfokgeiten (afhankelijk van de eerdere drachtresultaten). Het bedrijf produceert geitenlammeren voor vervanging van de eigenmelkgeiten, fokgeitjes en fokbokjes voor de verkoop en vleesbokjes.

- $\quad$ Alle lammeren worden kunstmatig opgefokt en worden direct na de geboorte bij de moeder weg geraapt. De navelstrengen worden op dat moment ontsmet met CTC-spray. Per 5 stuks worden ze geplaatst in betonplex-bakken op een rooster met houtkrullen en onder warmtelampen.

- De foklammeren krijgen 3 maal daags voeding, waarvan de eerste 2 voedingen handmatig kunstbiest en daarna 2 melkvoedingen. De opgenomen voeding wordt per dier geregistreerd. De vleesbokjes krijgen ook kunstbiest of, indien voorradig, biest van de opfokgeiten (eersteworps geiten). De biest wordt verstrekt op 3 vaste momenten per dag, 's ochtends, 's middags en 's avonds. Dus niet meteen bij het rapen. Na 2 biestgiften en 2 melkgiften gaan ze uit deze bakken naar groepen van 15-20 lammeren waar ze gevoerd worden via de lambar waar ze melkpoederproduct krijgen (=nulproduct).

- Na controle op goed drinken aan de bar worden ze in een grotere groep tot 55 lammeren geplaatst. De lammeren worden in afdelingen gehuisvest met 110 lammeren $(2 \times 55)$. De foklammeren, (overwegend geitjes en in de KI aflam-periode van december ook een koppel bokjes) en de vleesbokjes worden in gescheiden afdelingen gehuisvest. Zodra een afdeling vol zit, worden de een volgende afdeling bevolkt (All in, All out systeem). De vleesbokjes worden antibioticavrij opgefokt. Er vinden geen standaard koppelbehandelingen plaats gedurende de opfok aan de lambar.

Op bedrijf 2 werden 3000 melkgeiten gehouden. Jaarlijks worden de lammeren in 3 perioden geboren, te weten februari, juni en oktober. Elke periode werpen respectievelijk rond de 500 geiten, ongeveer 350 opfokgeiten en ongeveer 150 melkgeiten samen in totaal rond de 800 lammeren. Het bedrijf produceert jaarlijks circa 1200 ( 3 X400) geitenlammeren voor vervanging van de eigen melkgeiten, 200 fokbokken voor zowel eigen gebruik als verkoop en 1000 vleesbokjes.

- $\quad$ Alle lammeren worden kunstmatige opgefokt en direct na de geboorte bij de moeder weg gehaald (24 uurs assistentie). Ze raken in principe de pot niet aan door ze tijdens de geboorte op te vangen in een handdoek waarmee ze ook worden afgedroogd. De navelstrengen worden daarna ontsmet met onverdund "subliem concentraat plus" (=uierdip). Daarna worden de navelstrengen bekalkt met een handje actisan. Elk foklam wordt afzonderlijk in een kartonnen doosje geplaatst waarna ze in het doosje via een "hygiëneluik" in een klimaat-gecontroleerde zeecontainer komen (60\% luchtvochtigheid, $20-21^{\circ} \mathrm{C}$ ). De lammeren krijgen 3 keer biest in een periode van 16-17 uur waarbij de eerste gift binnen 1,5 uur na de geboorte. De biest wordt dagelijks gegeven om 6, 11, 16 en 21 uur. De lammeren die 's nachts geboren worden krijgen ook binnen 1,5 uur de eerste voeding. 's Nachts (ca. 02.00) krijgen de foklammeren een tweede biestvoeding, als ze 's avonds om 21 u de eerste hebben gehad. In de eerste twee giften krijgen de lammeren gepasteuriseerde biest van de eigen geiten uit eerste melkbeurt na werpen. De Brix-waarde van de biest wordt gemeten met de Brix Refractometer. Dit geeft een indicatie van de biestkwaliteit qua hoeveelheid antistoffen. De gemeten waarden in de biest liggen boven de 22 en worden beschouwd als goed. Door monitoring is bekend dat de para prevalentie op het bedrijf gering is en daarom durven ze eigen geitenbiest te voeren. De derde en laatste biestgift bestaat uit koeienbiest van bedrijven met een gecontroleerde ParaTBC status. De respectievelijke drinkvolumes zijn 150 tot $200 \mathrm{ml}, 200 \mathrm{ml}$ en $200 \mathrm{ml}$. Afwijkende opnames worden geregistreerd. De vleesbokjes krijgen 3 voedingen tweede keus koeienbiest in dezelfde drinkvolumes en van dezelfde gecontroleerde bedrijven. 
- Na de laatste biestgift worden de lammeren uit de doos vanuit de zeecontainer geplaatst in een hokje in een andere stal met 6 tot 7 lammeren waar ze met een drinkautomaat worden gevoerd. Op 4 tot 5 dagen leeftijd gaan de lammeren op transport naar de opfoklocatie en komen in groepen van 40-50 lammeren op $36 \mathrm{~m}^{2}$. Er vinden geen standaard koppelbehandelingen plaats gedurende de opfok aan de lambar. Tot $15 \%$ van de lammeren ontwikkelt een gewrichtsontsteking.

\subsection{Resultaten monitoring}

Op bedrijf 1 zijn 77 lammeren gemonitord welke geboren waren tussen 18 en 29 januari 2016. Dit betroffen allemaal opfokgeitjes. De navelstrengen zijn beoordeeld op 25, 27 en 29 januari en/of op 1 februari tot de navelstreng was opgedroogd en geheeld. Op 12 februari zijn de navelstrengen van alle lammeren nogmaals beoordeeld. De lammeren op bedrijf 1 waren gemiddeld 2,6 dagen oud bij de eerste waarneming en wogen op dat moment gemiddeld 3,8 kg. De diameter van hun navelstreng bij aanhechting was 7,2 mm met een gemiddelde lengte van de navelstreng tussen de 5 en $10 \mathrm{~cm}$. Op bedrijf 2 zijn 50 lammeren gemonitord welke geboren waren op 16, 17 en 18 februari. Dit waren 44 opfokgeitjes en 6 fokbokjes. De navelstrengen zijn beoordeeld op 18 en 22 februari en 3 maart. De lammeren op bedrijf 2 waren gemiddeld 0,7 dagen oud bij de eerste waarneming en wogen op dat moment gemiddeld 3,5 kg. De diameter van hun navelstreng bij aanhechting was 9,3 mm met een gemiddelde lengte van de navelstreng tussen de 5 en $10 \mathrm{~cm}$. Omdat op beide bedrijven een verschillend aantal keren gemonitord is, worden de resultaten per bedrijf weergegeven.

Op bedrijf 1 zijn 11 extra lammeren in de proef genomen die ouder waren dan 3 dagen voor een indicatie van de duur tot het afvallen van de navelstreng.

Tabel 1. Gemiddelden per bedrijf tijdens de eerste meetdag

\begin{tabular}{|c|c|c|c|c|c|}
\hline Bedrijf & Aantal & Leeftijd (dag) & Gewicht (kg) & $\begin{array}{l}\text { Diameter } \\
\text { navelstreng }(\mathrm{mm})\end{array}$ & $\begin{array}{l}\text { Lengte navelstreng } \\
\text { (categorie) }\end{array}$ \\
\hline 1 & 76 & $2.6(0-8)$ & $3.8(2.4-7.9)$ & $7.2(4.5-12.1)$ & $3(1-4)$ \\
\hline 2 & 50 & $0.7(0-2)$ & $3.5(2.3-5.1)$ & $9.3(6.3-16.7)$ & $3(1-4)$ \\
\hline
\end{tabular}

Van één lam op bedrijf 1 ontbreken de startwaarnemingen.

\subsection{Indroging}

Minimaal 90\% van de lammeren op bedrijf 1 had binnen 7 dagen een opgedroogde/gemummificeerde navelstreng. Gemiddeld waren deze lammeren 3 dagen oud toen hun navelstreng volledig was gemummificeerd. Op bedrijf 1 hadden alle beoordeelde lammeren van 6 dagen of ouder een volledig gemummificeerde navelstreng (Tabel 2).

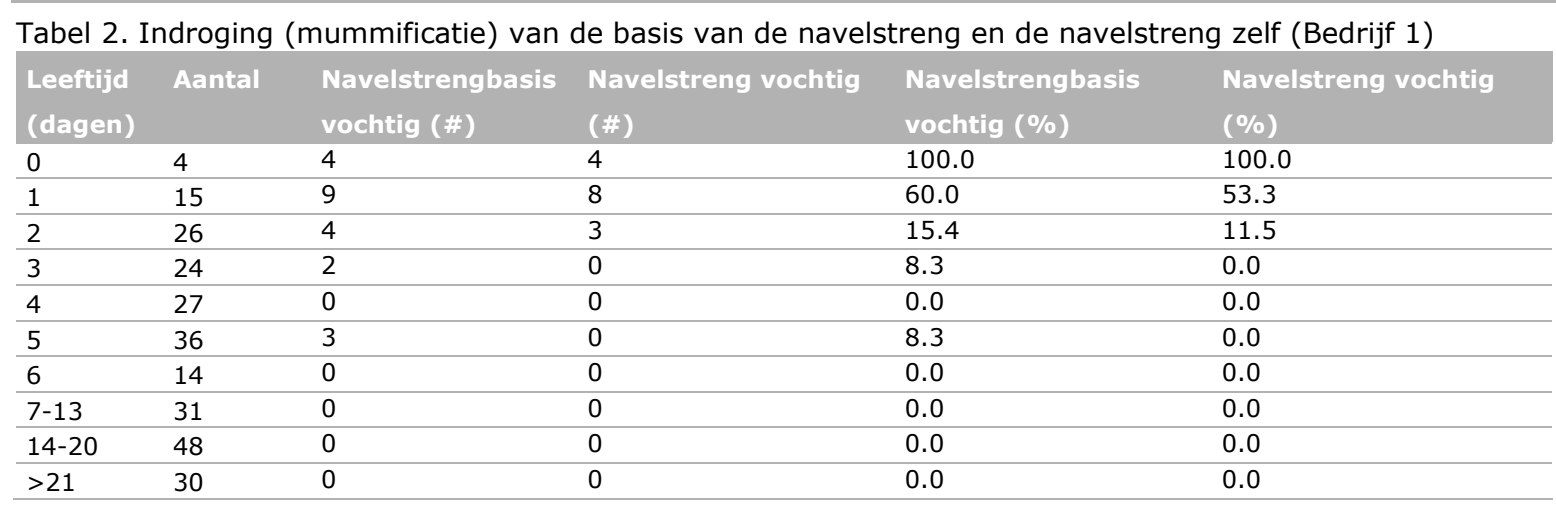


Minimaal 98\% van de lammeren op bedrijf 2 heeft na 7 dagen een gemummificeerde navelstreng. Gemiddeld waren deze lammeren 4 dagen oud toen hun navelstreng volledig was gemummificeerd. Op bedrijf 2 hadden alle beoordeelde lammeren van 5 dagen of ouder een volledig gemummificeerde navelstreng (Tabel 3).

\begin{tabular}{|c|c|c|c|c|c|}
\hline 0 & 17 & 17 & 17 & 100.0 & 100.0 \\
\hline 1 & 29 & 19 & 14 & 65.5 & 48.3 \\
\hline 2 & 4 & 2 & 0 & 50.0 & 0.0 \\
\hline 6 & 4 & 0 & 0 & 0.0 & 0.0 \\
\hline $14-20$ & 49 & 0 & 0 & 0.0 & 0.0 \\
\hline
\end{tabular}

\subsection{Afvallen van de navelstrengen}

De lengte van de monitoringsperiode c.q. de leeftijd varieerde per lam op bedrijf 1 van 14 tot 25 dagen (tussen 18-29 januari geboren en op 12 februari de eindwaarneming). Op bedrijf 1 hadden 3 van de 76 lammeren (4\%) meteen bij de eerste waarneming na de geboorte al een korte navelstreng $(<1 \mathrm{~cm})$. Bij 39 lammeren $(51 \%)$ is de navelstreng er tijdens de monitoringsperiode afgevallen c.q. heeft de navelstreng 'natuurlijk' losgelaten tijdens het helingsproces. Gemiddeld waren deze lammeren 18 dagen oud toen dat is vastgesteld. Ze varieerde in leeftijd van 10 tot 25 dagen (Tabel 4). Na het afvallen van de navelstreng ontstond vaak een oppervlakkig huidwondje met of zonder een korstje. Buiten deze 42 lammeren om (3 plus 39), is bij 5 lammeren die na de geboorte aanvankelijk een navelstreng hadden met een lengte van meer dan $1 \mathrm{~cm}$, tijdens de monitoringsperiode de navelstreng korter afgebroken of afgescheurd. Aan het eind van de monitoringsperiode was bij $45 \%$ van de lammeren variërend in leeftijd van 14 tot 25 dagen de navel er nog niet af.

\begin{tabular}{llll}
\hline $\begin{array}{l}\text { Tabel 4. Loslaten van de navelstreng (Bedrijf } 1) \\
\text { Leeftijd (dagen) }\end{array}$ & Aantal & Navelstreng losgelaten (\#) & Navelstreng losgelaten (\%) \\
\hline 0 & 4 & 0 & 0.0 \\
\hline 1 & 15 & 0 & 0.0 \\
\hline 2 & 26 & 0 & 0.0 \\
\hline 3 & 24 & 0 & 0.0 \\
\hline 4 & 27 & 0 & 0.0 \\
\hline 5 & 36 & 0 & 0.0 \\
\hline 6 & 14 & 0 & 0.0 \\
\hline $7-13$ & 31 & 1 & 3.2 \\
\hline $14-20$ & 48 & 22 & 45.8 \\
\hline$>21$ & 30 & 17 & 56.7 \\
\hline
\end{tabular}

De lengte van de monitoringsperiode c.q. de leeftijd varieerde per lam op bedrijf 2 van 16 tot 18 dagen (tussen 16-18 februari geboren en op 3 maart de eindwaarneming). Op bedrijf 2 hadden 6 van de 50 lammeren ( $5 \%)$ meteen bij de eerste waarneming na de geboorte al een korte navelstreng $(<1$ $\mathrm{cm}$ ). Bij 4 lammeren ( $8 \%$ ) is de navelstreng er tijdens de monitoringsperiode afgevallen c.q. heeft de navelstreng 'natuurlijk' losgelaten tijdens het helingsproces. Na het afvallen van de navelstreng ontstond een oppervlakkig huidwondje met of zonder een korstje. Gemiddeld waren deze lammeren 15 dagen oud toen dat is vastgesteld (Tabel 5) (variatie in leeftijd: 14 of 15 dagen). Buiten deze 10 lammeren ( 6 plus 4), is bij 1 lam die na de geboorte aanvankelijk een navelstreng had met een lengte van meer dan $1 \mathrm{~cm}$, tijdens de monitoringsperiode de navelstreng kort afgebroken of afgescheurd. Aan het eind van de monitoringsperiode was bij $87 \%$ van de lammeren variërend in leeftijd van 16 tot 18 dagen de navel er nog niet af. 
Tabel 5. Loslaten van de navelstreng (Bedrijf 2)

\begin{tabular}{llll} 
Leeftijd & Aantal & Navelstreng losgelaten (\#) & Navelstreng losgelaten (\%) \\
(dagen) & & 0 & 0.0 \\
0 & 17 & 0 & 0.0 \\
\hline 1 & 29 & 0 & 0.0 \\
\hline 4 & 4 & 0 & 0.0 \\
\hline 5 & 17 & 0 & 0.0 \\
\hline 6 & 29 & 0 & 0.0 \\
\hline $14-20$ & 4 & 4 & 8.2 \\
\hline
\end{tabular}

\subsection{Afwijkende heling}

Op bedrijf 1 hadden 4 lammeren van 7 dagen of ouder (5\%) een zichtbaar afwijkend helingsproces, veroorzaakt door een ontsteking met navelcondities die afwijken van het normale helingsproces(tab. $6)$. Het gewogen gewicht en de gemeten diameter en lengte van de navelstrengen van deze afwijkende lammeren verschillen niet van de lammeren met een helingsproces van de navelstreng binnen 7 dagen. Op bedrijf 2 had geen enkel lam van 7 dagen of ouder een verstoord helingsproces (Tabel 6).

Tabel 6. Dieren met afwijkend helingsproces (Bedrijf 1)

\begin{tabular}{llllll} 
Bedrijf 1 & Aantal & Leeftijd & Gewicht & Diameter & Lengtecategorie \\
\hline Totaal aantal lammeren & 76 & 2.6 & 3.8 & 7.2 & 3.1 \\
\hline Normaal proces & 73 & 2.6 & 3.8 & 7.2 & 3.1 \\
\hline Afwijkend proces & 3 & 2.7 & 3.6 & 7.2 & 2.3
\end{tabular}

Van één lam met een afwijkend helingsproces ontbreken de startwaarnemingen

Op bedrijf 1 is bij 14 lammeren (19\%) de voel- en/of zichtbare verdikking bij de navelbasis opgemeten. Dit lijkt een vaker voorkomende fase in de heling (het vertraagde sluiten van de buikwand/optrekken van de vaten in de buikwand). Bij 3 lammeren werd de verdikking veroorzaakt door een ontsteking of een navelbreuk. De gemiddelde diameter bij deze 14 lammeren bedroeg bij de $1^{\text {ste }}$ vaststelling van de verdikking $14,9 \mathrm{~mm}$ en varieerde van 9,2 $\mathrm{mm}$ tot $22,5 \mathrm{~mm}$. Deze 15 lammeren varieerde bij de 1 ste vaststelling in leeftijd van 1 tot 13 dagen oud. Bij 4 lammeren is op meerdere momenten een verdikking vastgesteld. $\mathrm{Bij} 1 \mathrm{lam}$ is 4 keer gedurende het helingsproces de diameter gemeten, waarbij de diameter van de verdikking eerst toenam en later, van 27 januari tot 1 februari, steeds verder afnam, van 16,5 naar 9,3mm. De navelstreng zelf was $8,5 \mathrm{~mm}$ in diameter.

Op bedrijf 2 zijn uitsluitend de zichtbare verdikkingen nog opgemeten. Op bedrijf 2 is bij slechts 2 lammeren (4\%) een verdikking op het oog vastgesteld. Deze waren ongeveer 15 dagen oud. Dit betrof in ieder geval 1 keer een navelbreuk (Tabel 7).

Tabel 7. Dieren met verdikking bij navelbasis

\begin{tabular}{lllll} 
Bedrijf & Aantal & Leeftijd & Diameter navelstreng $(\mathrm{mm})$ & Diameter verdikking $(\mathrm{mm})$ \\
Bedrijf 1 & 14 & $7(1-13)$ & $7.1(4.9-10.4)$ & $14.9(9.2-22.5)$ \\
\hline Bedrijf 2 & 2 & $15(14-16)$ & $10.8(10.3-11.3)$ & $18.6(18.0-19.2)$
\end{tabular}




\section{$3.6 \quad$ Fotoseries}
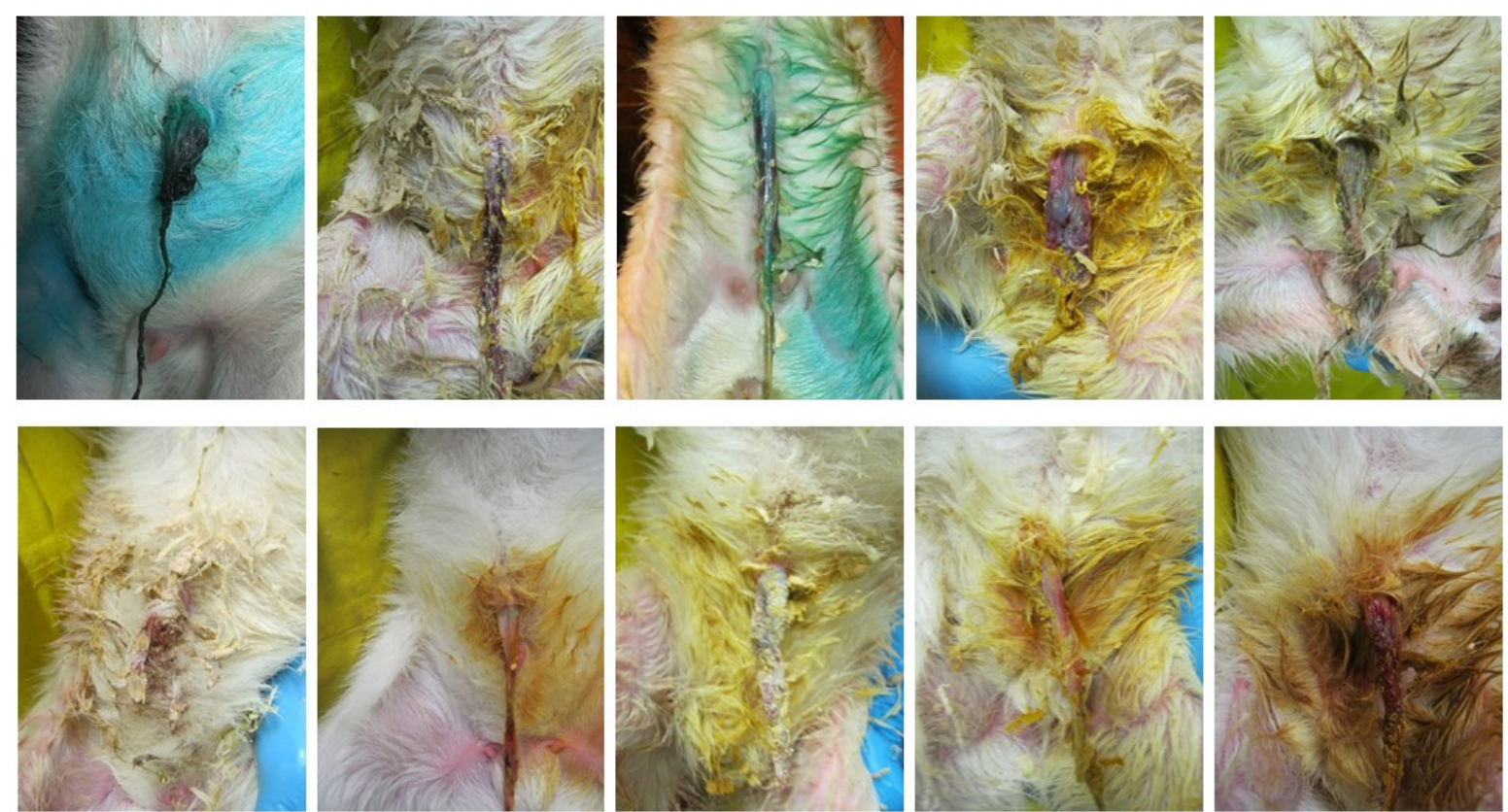

Figuur 3.6.1 Navelstrengen op dag 0.
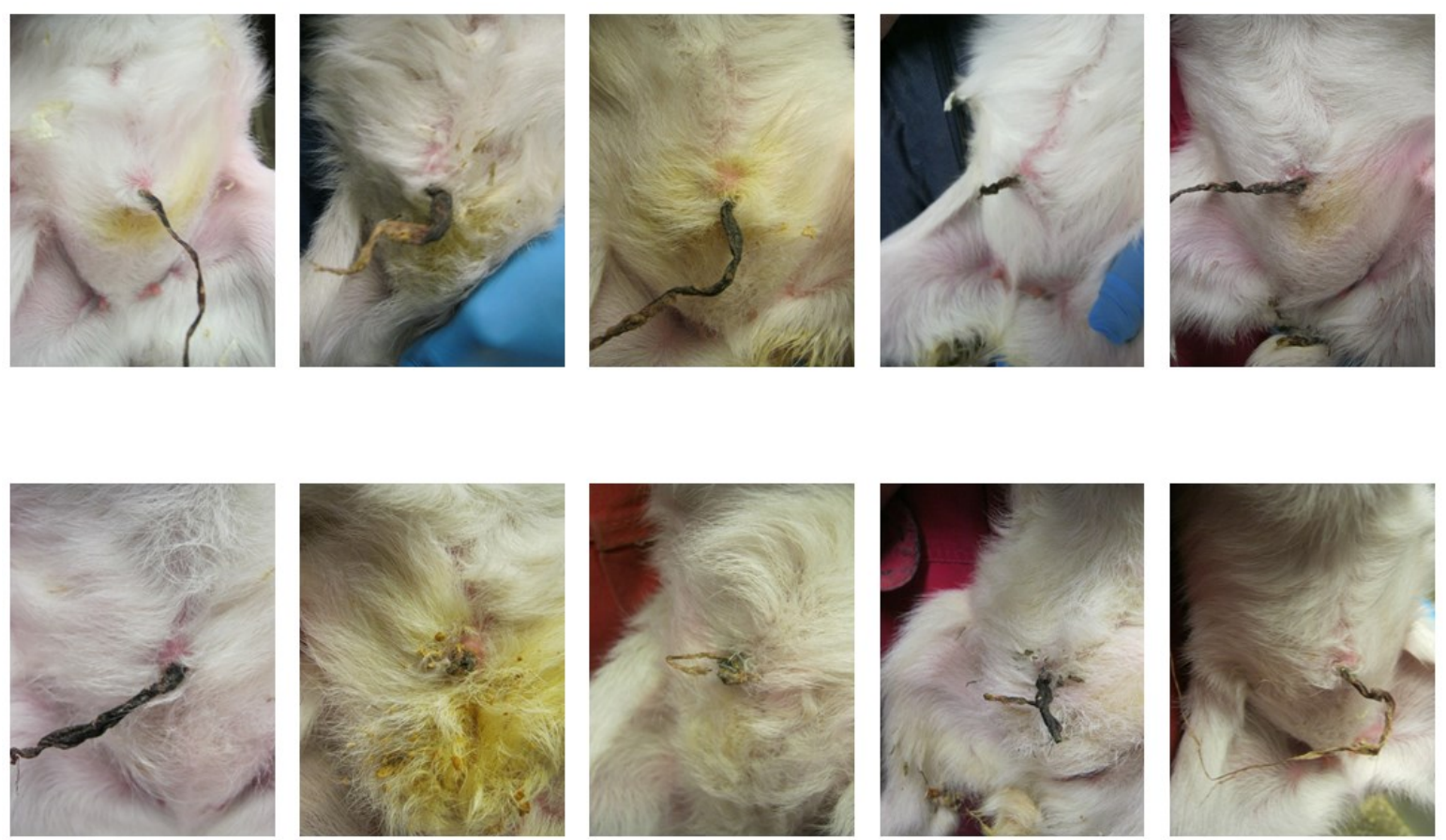

Figuur 3.6.2 Navelstrengen op dag 4-5. 

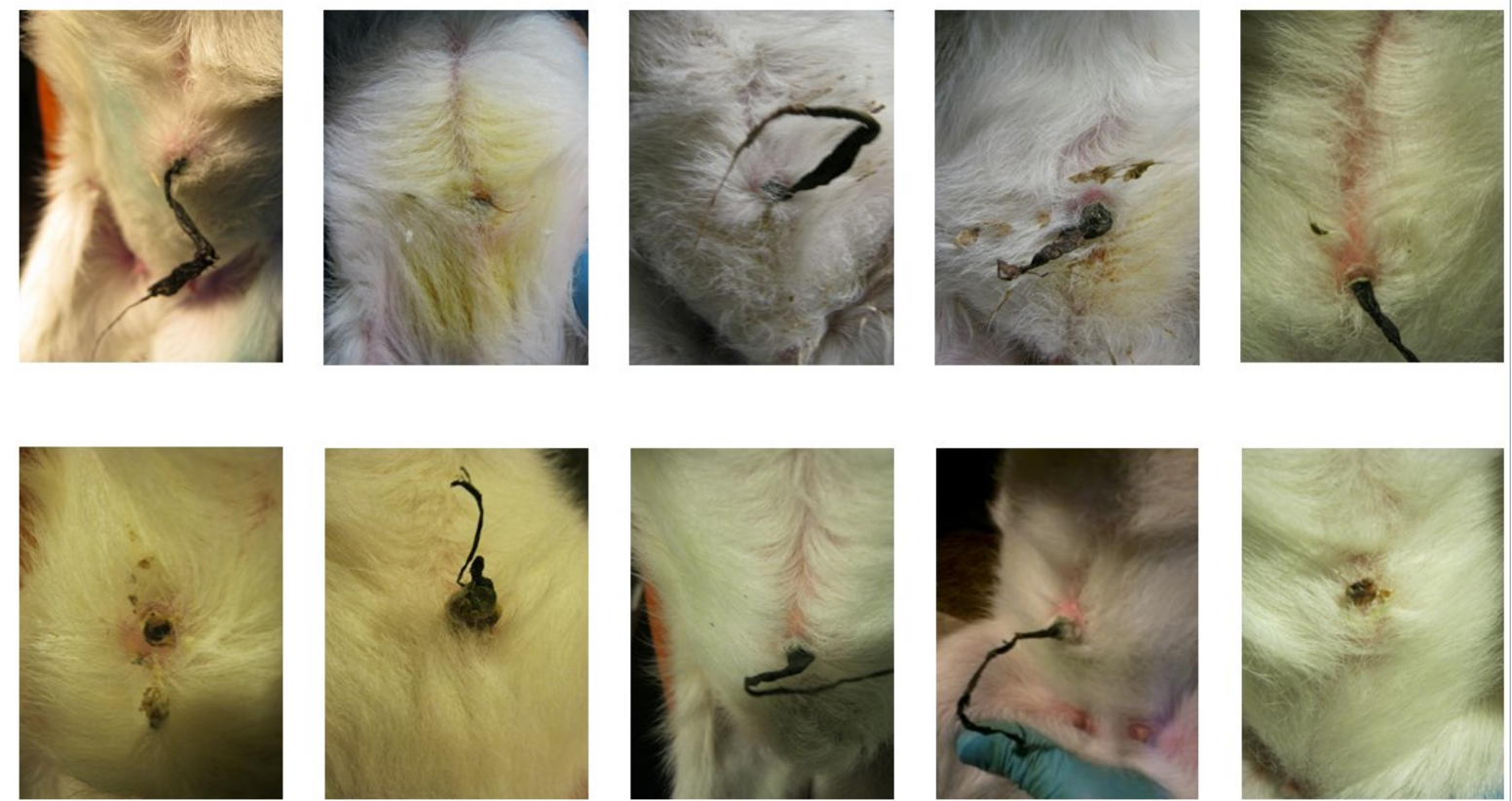

Figuur 3.6.3 Navelstrengen op dag 6-7.
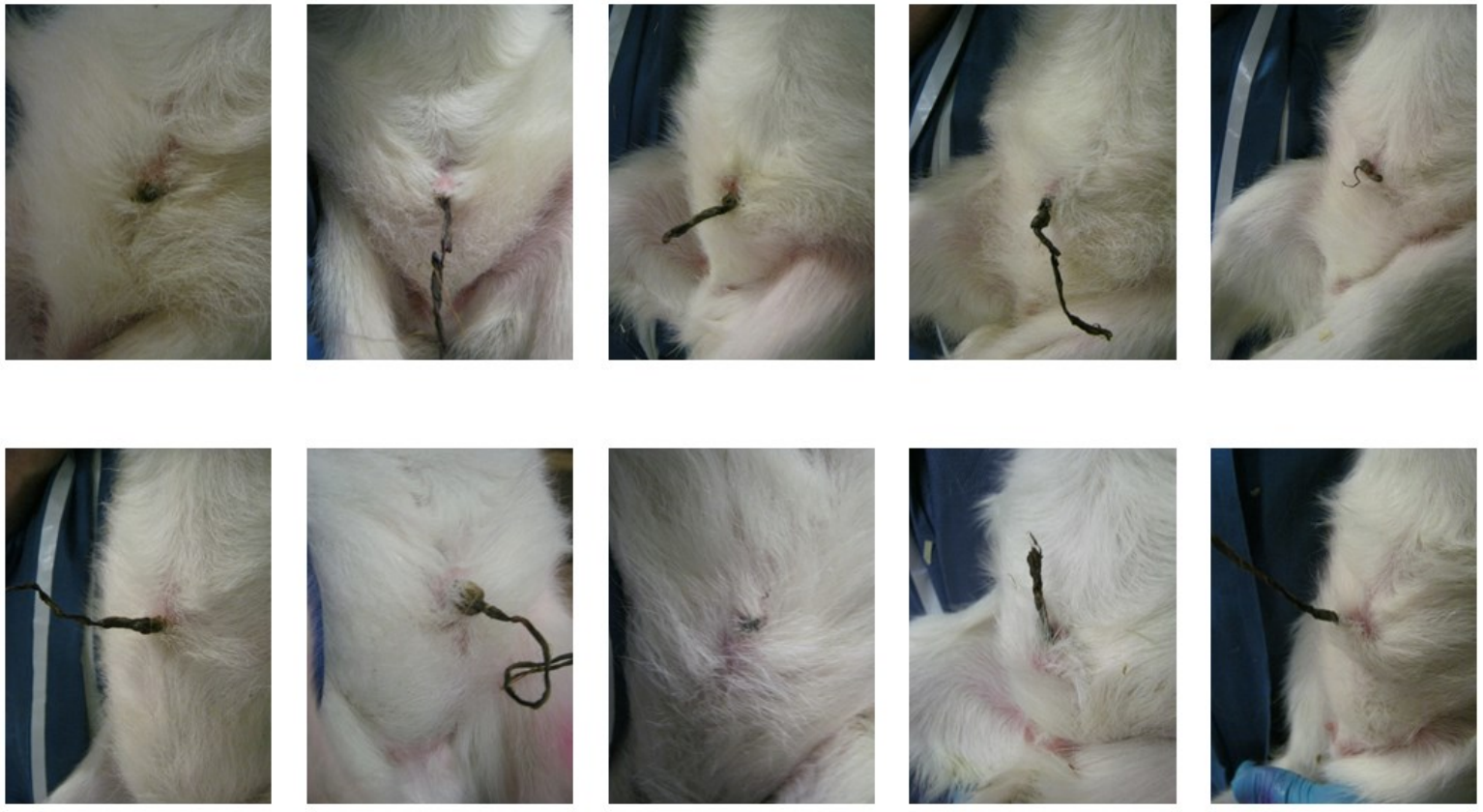

Figuur 3.6.4 Navelstrengen op dag 14-15. 

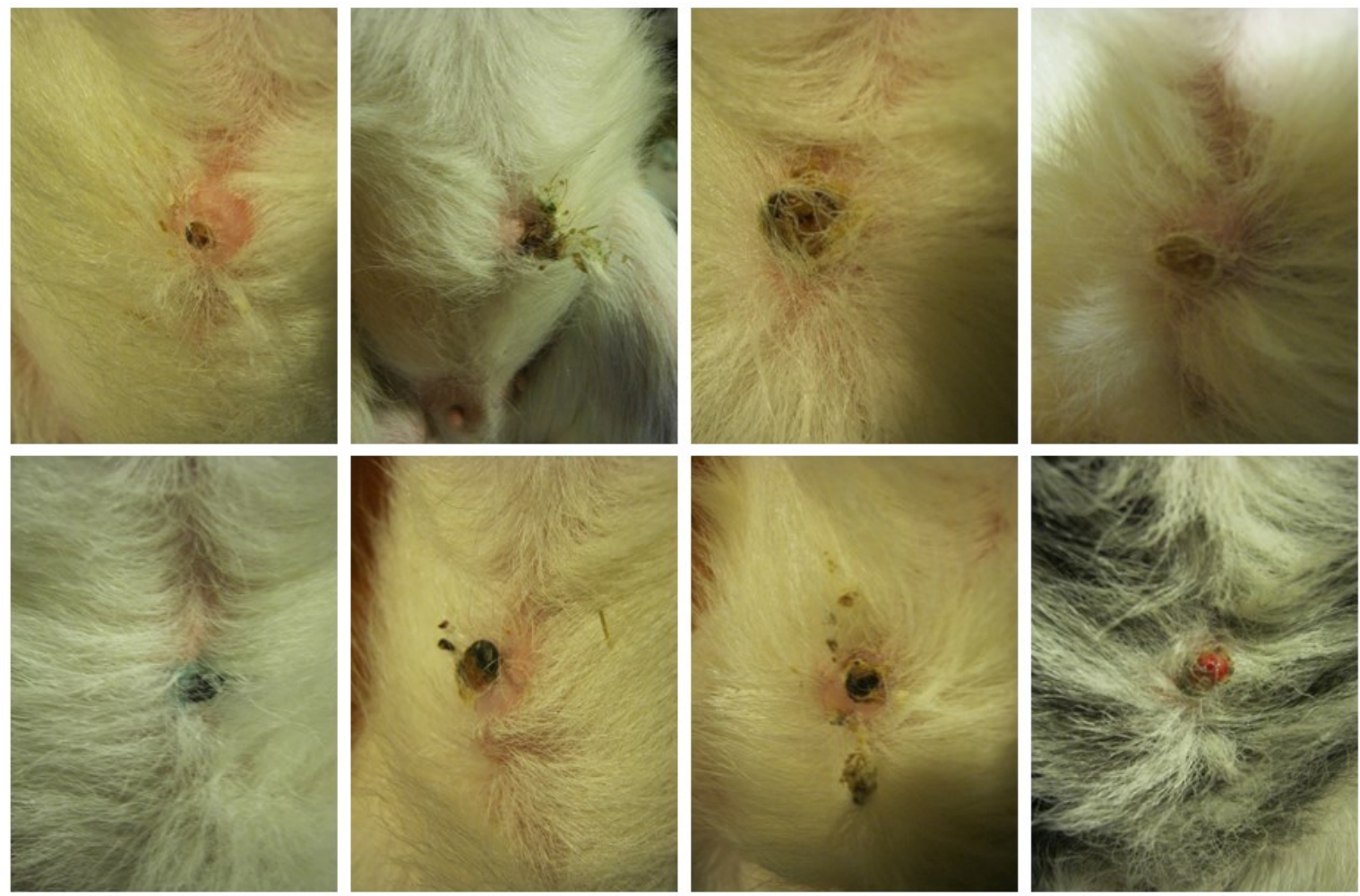

Figuur 3.6.5 Afgevallen navelstrengen na dag 20.

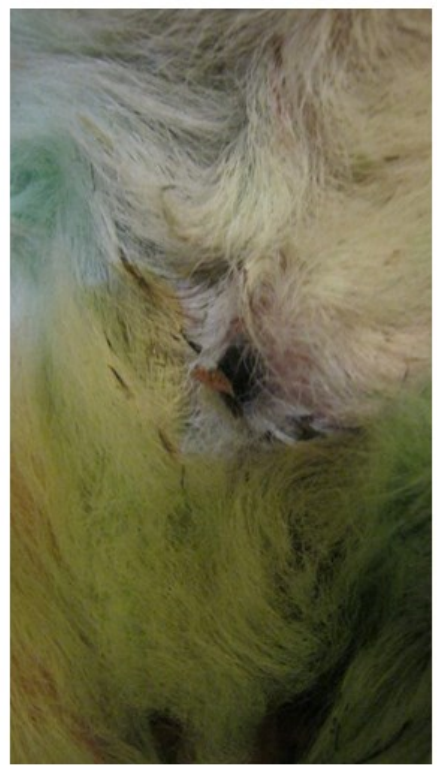

Dag 1

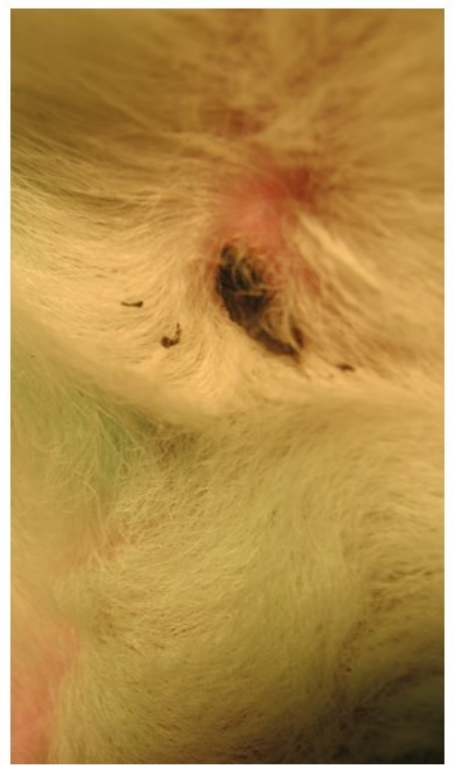

4

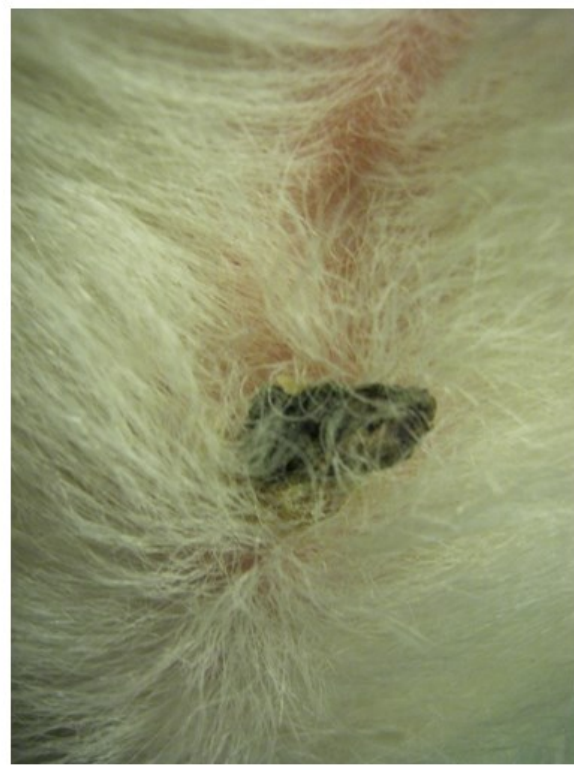

15

Figuur 3.6.6 Indrogingsproces. 


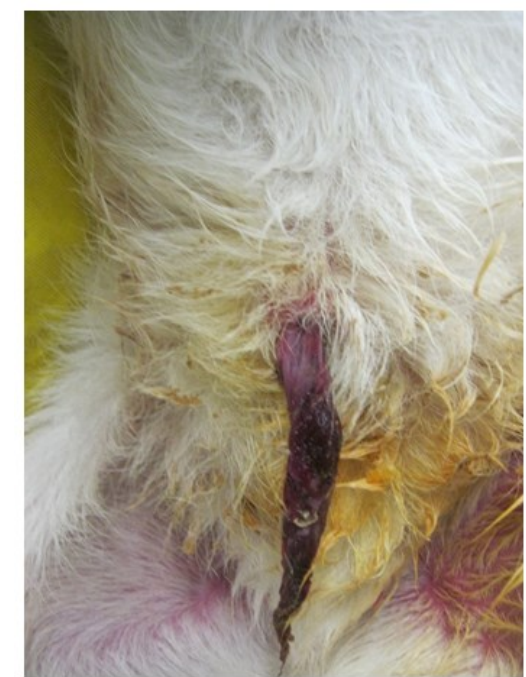

Dag 0

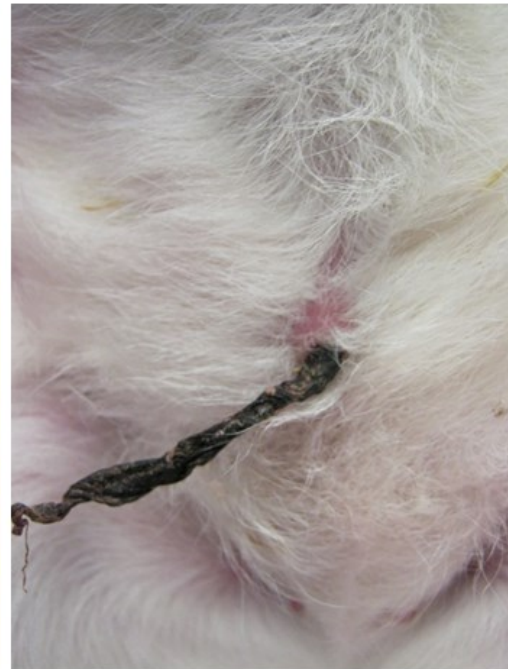

4

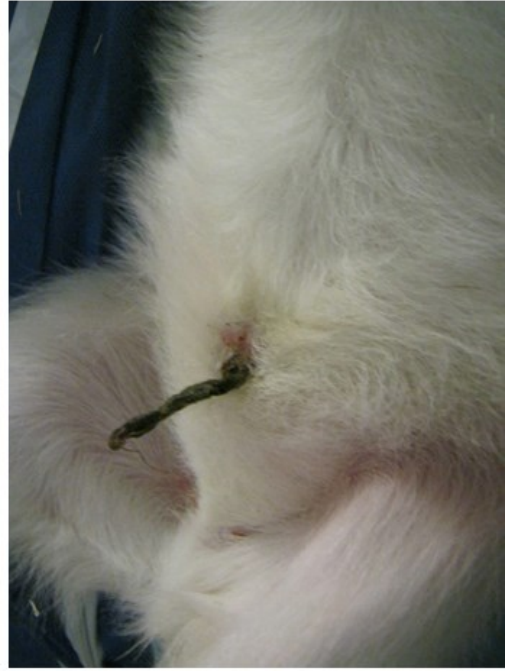

14

Figuur 3.6.7 Indrogingsproces.

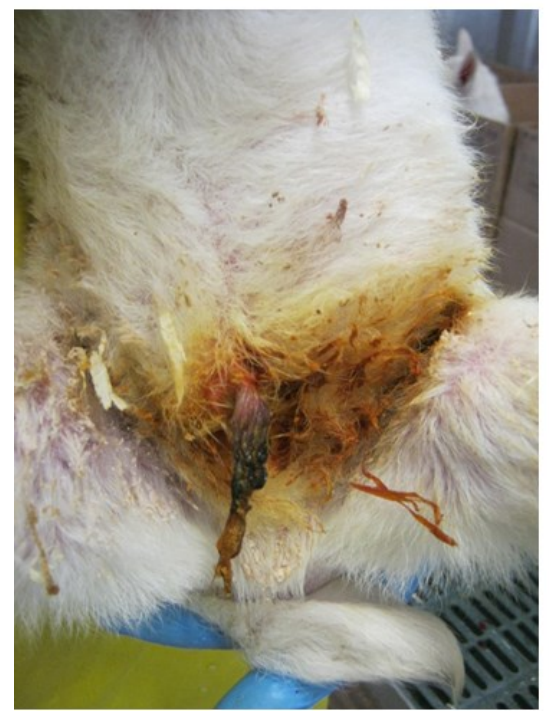

Dag 1

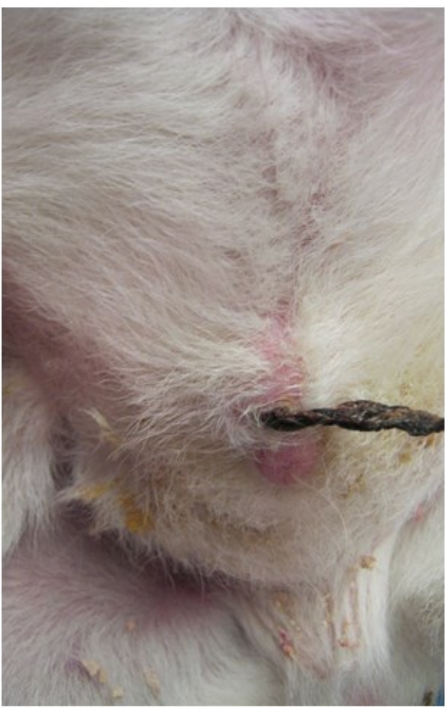

5

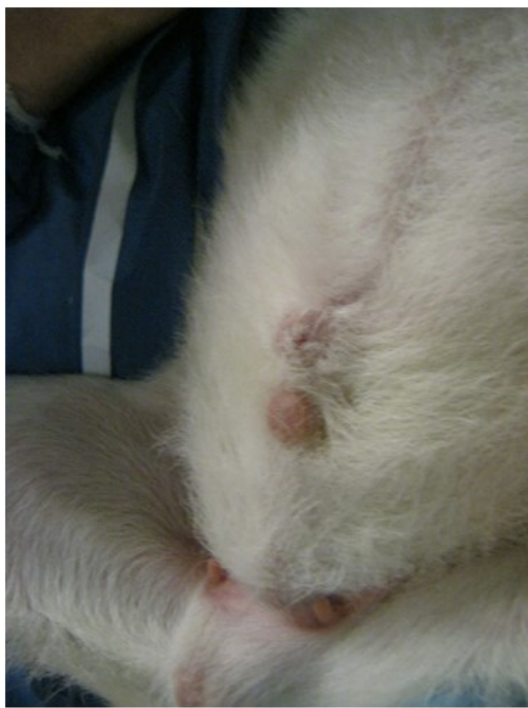

15

Figuur 3.6.8 Indrogingsproces. 


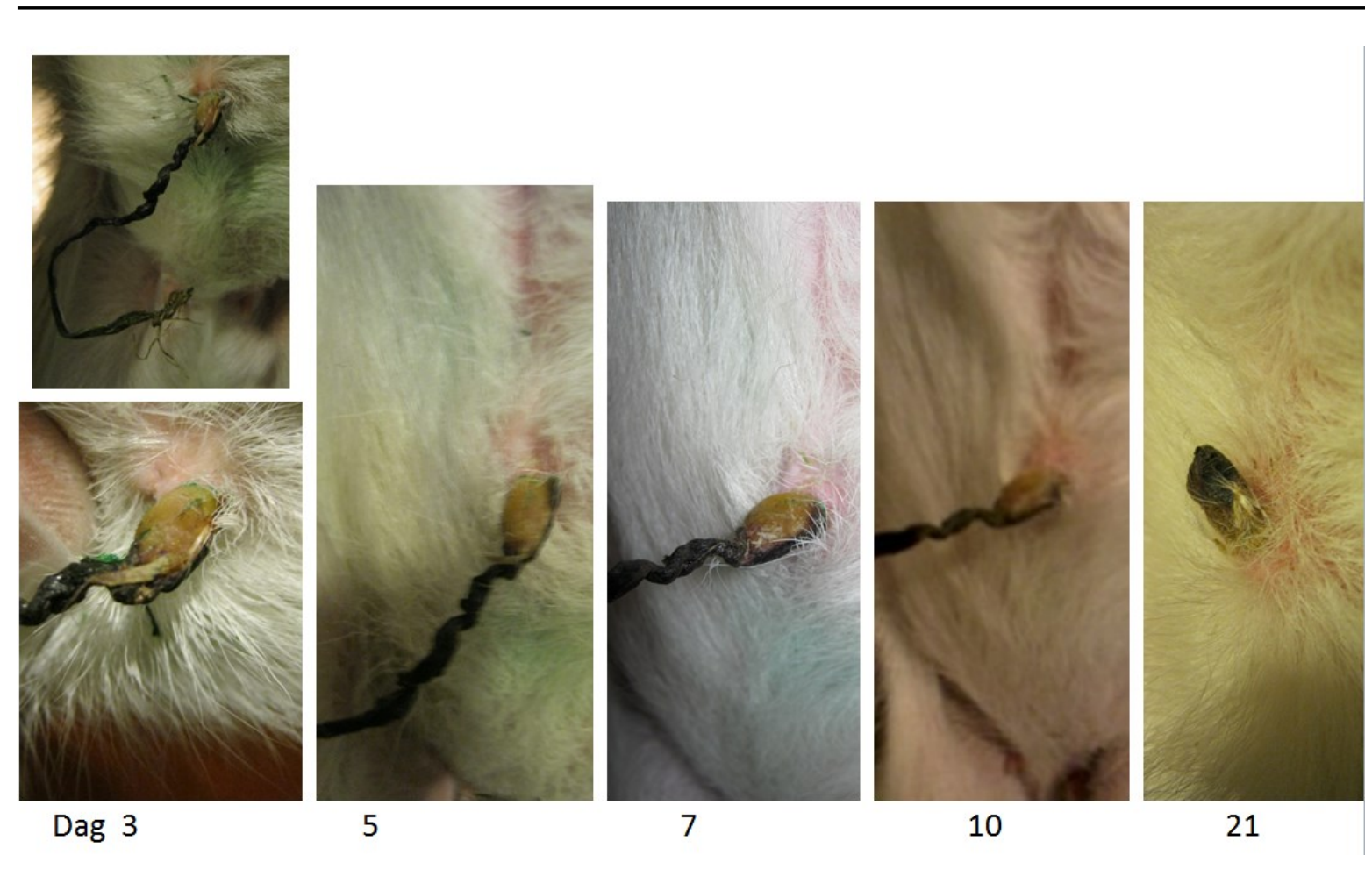

Figuur 3.6.9 Indrogingsproces.

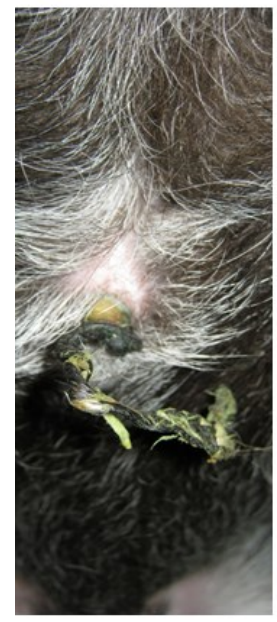

Dag 3

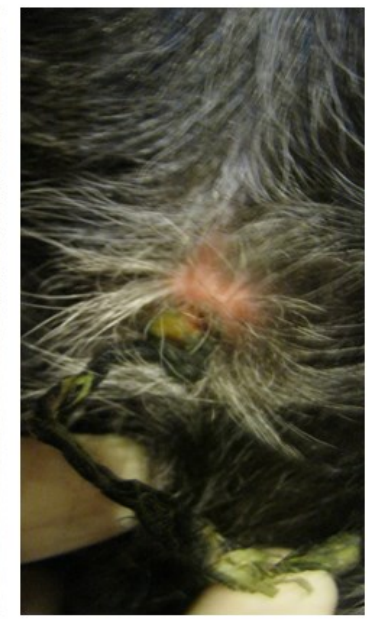

5

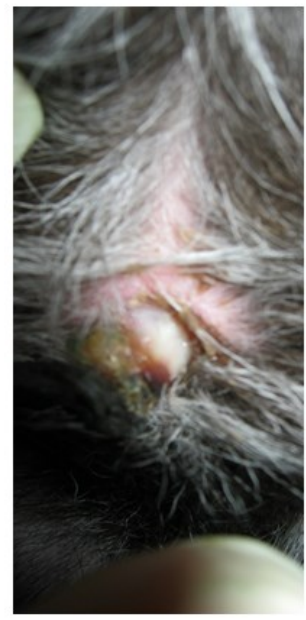

7

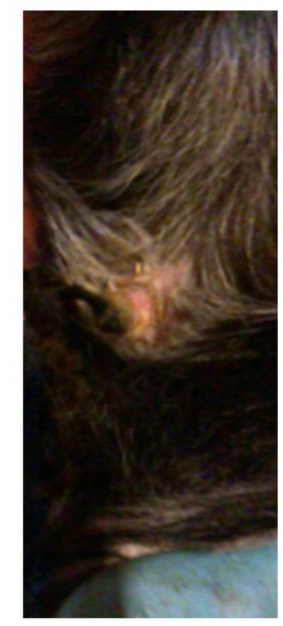

10
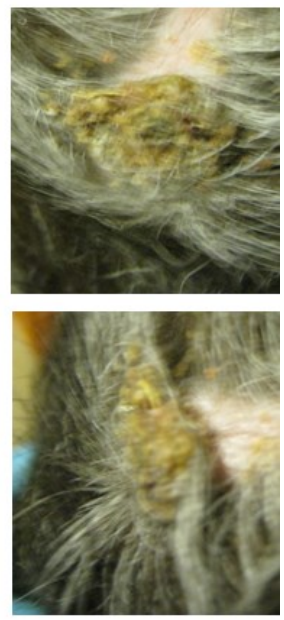

21

Figuur 3.6.10 Indrogingsproces met ontsteking bij navelbasis. 


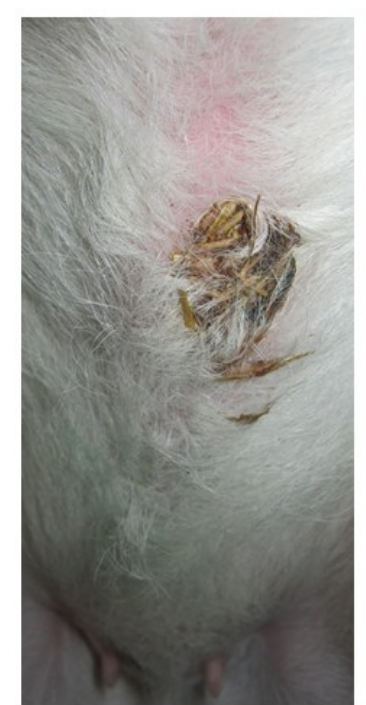

Dag 8

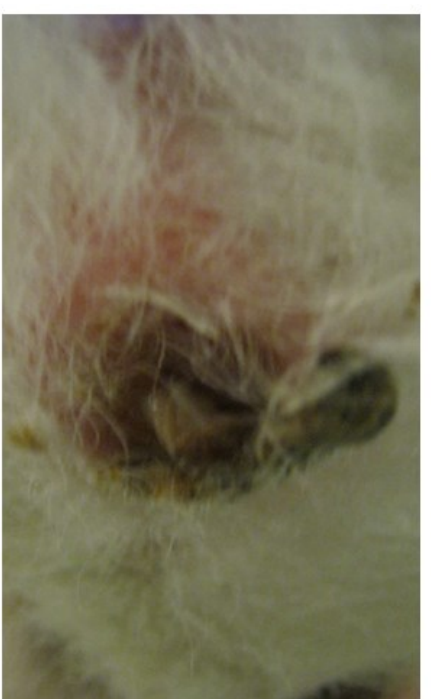

10

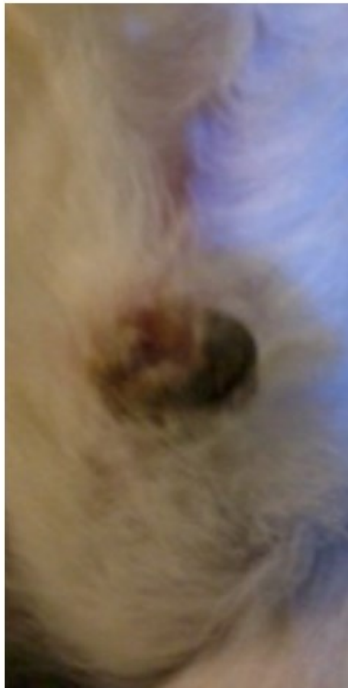

13

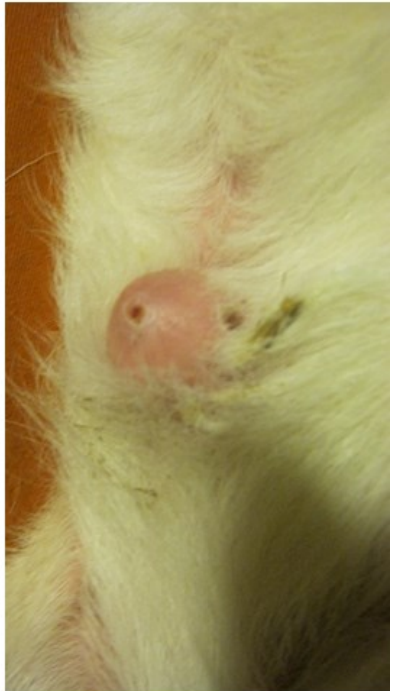

24

Figuur 3.6.11 Indrogingsproces met navelbreuk. 


\section{Conclusies}

Uit deze studie blijkt dat de mummificatie van de navelstreng het enige bruikbare criterium is om het helingsproces van de navelstreng van geitenlammeren uitwendig te kunnen beoordelen. Een gemummificeerde (ingedroogde) navel wordt beschouwd als voldoende uitwendige heling van de navel. De duur van het mummificatieproces varieerde op deze bedrijven van 1 tot 6 dagen waarbij het gros reeds op 4 dagen na de geboorte een volledig gemummificeerde navel heeft en de helft al na 2 dagen. Op een leeftijd van 7 dagen lijkt de mummificatie van de navelstreng van alle geitenlammeren voltooid. Een geitenlam met een onvolledig gemummificeerde navel is naar alle waarschijnlijkheid nog geen 7 dagen oud. Als sprake is van onvolledige mummificatie van de navel of van een afwijkende heling ten gevolge van een navelbreuk of een ontsteking, is de navel nog niet geheeld en mag het geitenlam niet op transport over de openbare weg.

Op een leeftijd van 7 dagen laten de navelstrengen van geitenlammeren nog niet los. Op dag 7 kunnen de navelstrengen wel kort zijn door afscheuren tijdens de geboorte of afbijten door het moederdier tijdens het drooglikken. $\mathrm{Er}$ is een grote variatie in lengte van de navelstreng. In respectievelijk 4\% en 5\% van de gevallen was de navelstreng al kort (afgescheurd/afgebeten) bij de geboorte. De lengte van de navelstreng is derhalve geen goede parameter voor de mate van de genezing van de navelstreng (en vervalt als indicator voor de leeftijd van de lammeren).

Op bedrijf 1 is $50 \%$ van de navelstrengen afgevallen op gemiddeld 18 dagen na geboorte. Op bedrijf 2 is dat $8 \%$ op dag 15 . De verwachting is dat de gemiddelde leeftijd voor $100 \%$ afgevallen navels ergens rond de 3 weken zal liggen. De benodigde tijd voor het afvallen van het gemummificeerde navelstrengweefsel van geitenlammeren lijkt in vergelijking tot kalvernavels meer tijd te vergen (zoals beschreven in het rapport van Bostedt). In het rapport van prof. H. Bostedt van de Justus-Liebig Universiteit te Giessen gaat men voor kalveren uit van 10-14 dagen tot het afvallen van het gemummificeerde weefsel en aansluitend nog eens 2-4 dagen voor het genezen van het navelwondje. Ook in dit onderzoek zijn na het afvallen van de navelstreng nog oppervlakkige wondjes met/zonder een korstje gezien.

Een verband tussen aan de ene kant het geboortegewicht, de diameter van de navelstreng of de lengte van de navelstreng en aan de andere kant het helingproces lijkt er niet te zijn. De diameter en de lengte van de navelstreng geven tot aan het moment van afvallen geen betrouwbare indicatie over het stadium van het helingsproces, noch over de leeftijd van de lammeren. Het spreekt voor zich dat oudere lammeren toenemen in gewicht en het aandeel geheelde navels zal groter zijn naarmate de lammeren toenemen in gewicht. De groei is echter in sterke mate afhankelijk van het management, wat van bedrijf tot bedrijf en per seizoen binnen bedrijf sterk kan variëren.

Een beperkt aantal lammeren heeft een helingsproces dat langer duurt dan 7 dagen al dan niet gepaard gaande met ontstekingen. Een voel -of zichtbare verdikking bij de aanhechting van de navelstreng duidt op een onvolledige heling en komt ook voor bij lammeren ouder dan 7 dagen.

Deze inventarisatie van het helingsproces van geitennavels is uitgevoerd op 2 reguliere melkgeitenbedrijven en vooral bij opfokgeitjes en een beperkt aantal fokbokjes. Door dit beperkt aantal bedrijven, is het slechts mogelijk om indicaties te geven over de duur van het mummificatieproces, de duur tot het afvallen van de navel en het percentage geitenlammeren afwijkende heling van de navels en moeten deze indicaties niet gezien worden als representatieve gemiddelden voor geitenlammeren (bokjes én geitjes) van alle bedrijven in Nederland. 


\section{Literatuur}

Bostedt, H. Prof. Dr., 1997. Gutachterliche stellungnahme zur tierschutzrelevanten frage üver die transportfähigkeit junger kälber, Giessen. 


\section{Bijlage 1 Scoringsprotocol}

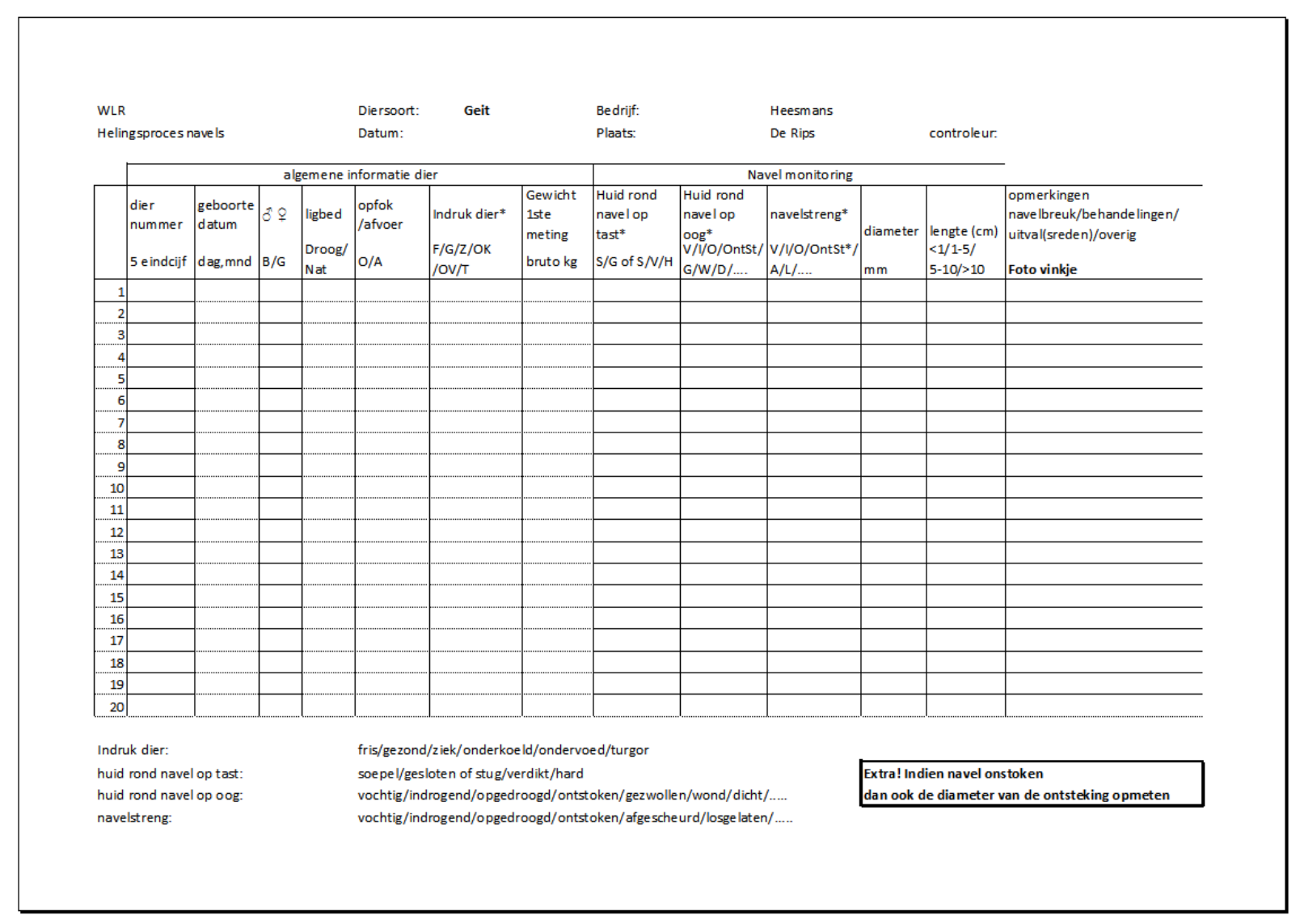



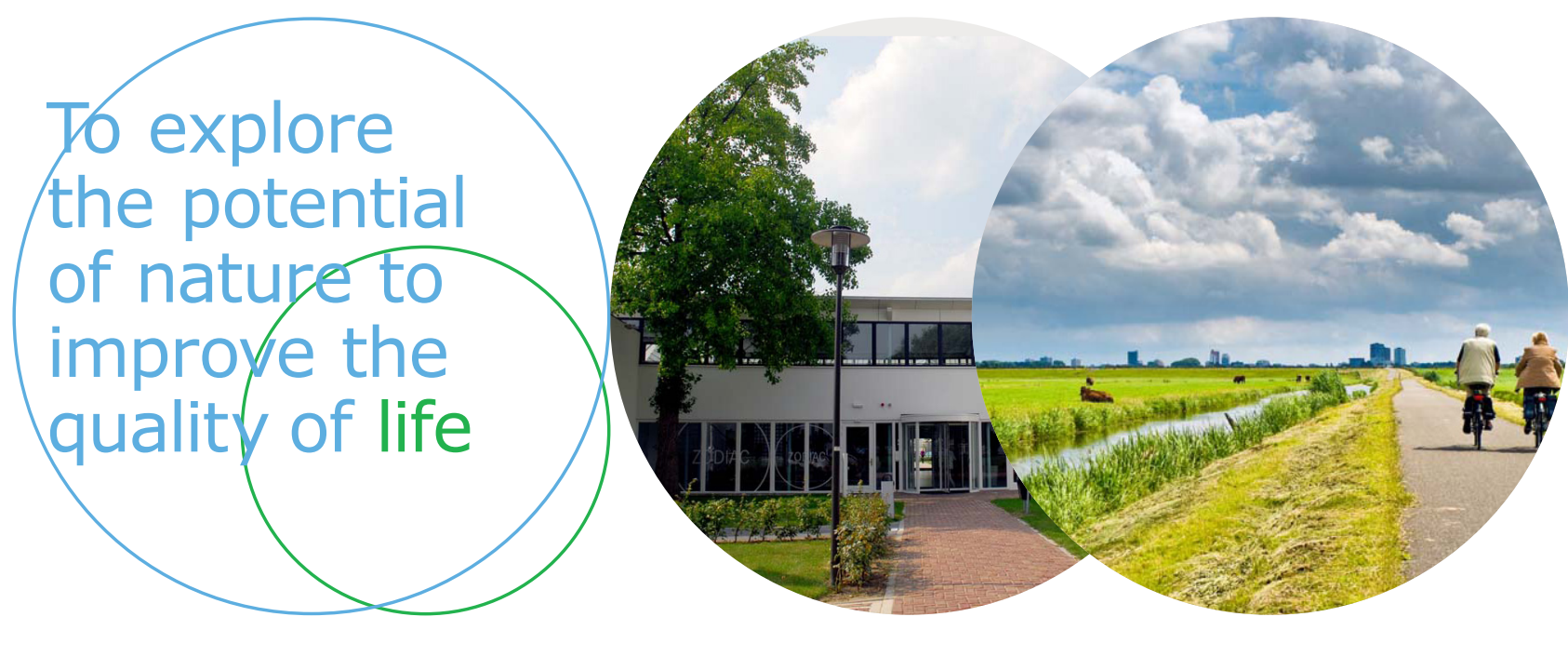

Wageningen Livestock Research Postbus 338

$6700 \mathrm{AH}$ Wageningen

T 0317483953

E info.livestockresearch@wur.nl www.wur.nl/livestock-research
Wageningen Livestock Research ontwikkelt kennis voor een zorgvuldige en renderende veehouderij, vertaalt deze naar praktijkgerichte oplossingen en innovaties, en zorgt voor doorstroming van deze kennis. Onze wetenschappelijke kennis op het gebied van veehouderijsystemen en van voeding, genetica, welzijn en milieu-impact van landbouwhuisdieren integreren we, samen met onze klanten, tot veehouderijconcepten voor de 21 e eeuw.

De missie van Wageningen University \& Research is 'To explore the potential of nature to improve the quality of life'. Binnen Wageningen UR bundelen 9 gespecialiseerde onderzoeksinstituten van stichting DLO en Wageningen University hun krachten om bij te dragen aan de oplossing van belangrijke vragen in het domein van gezonde voeding en leefomgeving. Met ongeveer 30 vestigingen, 6.000 medewerkers en 10.000 studenten behoort Wageningen UR wereldwijd tot de aansprekende kennisinstellingen binnen haar domein. De integrale benadering van de vraagstukken en de samenwerking tussen verschillende disciplines vormen het hart van de unieke Wageningen aanpak. 